Diyala Journal

Sciences

Vol. 06, No. 03, pp. 144-157, September 2013

\title{
COMPARISON BETWEEN MEMBRANE THEORY AND FINITE ELEMENTS ANALYSES FOR DOMED SHELLS EDGED BY SUPPORT RING BEAM
}

\author{
Khattab Saleem AbdulRazzaq ${ }^{1}$, Waad A. Zakaria ${ }^{2}$, Ali AlAmawy ${ }^{3}$ \\ $1,2,3$ College of engineering, Diyala University \\ Email:dr.khattabsaleem@yahoo.com ${ }^{1}$,waadzakariya@yahoo.com ${ }^{2}$ \\ (Received: 18/11/2009;Accepted: 7/2/2012)
}

\begin{abstract}
Domes are back again in Iraq. They are early recognized with specific houses of those who consider them a symbol of Iraqi architecture, beauty and luxury at the same time.

Nowadays, domes are widely implemented. Domes, built with brick, reinforced concrete or steel; separated or overlapped are widely implemented ${ }^{(5)}$.

In order to achieve fast and accurate dome designs, we must to be familiar with how domes behave under various types of loads and boundary conditions.

This humble work illustrates the deduced results of membrane theory and finite element to address specific cases in which fast and easy membrane theory results cannot be adopted directly by recommending other ways in order to get an accurate implementation of membrane theory in harmony with engineering sense.

Several types of loading applied on a spherical dome -as an example- in this research to get results which were analyzed, discussed and then recommendations were presented in this paper.
\end{abstract}

\section{List of Symbols:}

C Concentrated force applied on the dome crown like lantern or ornament.

D Shell span.

F Horizontal component of the meridional force $\mathrm{T}$.

$\mathrm{H} \quad$ Shell rise.

$\mathrm{H} \quad$ Hoop or latitude force resultant.

$\mathrm{H}_{\mathrm{FS}} \quad$ Hoop or latitude force given by finite element analysis for fixed supported dome. 
$\mathrm{H}_{\mathrm{SS}} \quad$ Hoop or latitude force given by finite element analysis for simply supported dome.

$\mathrm{R} \quad$ Shell radius.

T Shell thickness.

T Thrust or meridional force resultant.

$\mathrm{T}_{\mathrm{FS}} \quad$ Thrust or meridional force given by finite element analysis for fixed supported dome.

TSS Thrust or meridional force given by finite element analysis for simply supported dome.

$\mathrm{W}_{\mathrm{D}} \quad$ Uniformly distributed load on the shell body which represents the self-weight of the dome in the calculations.

$\mathrm{W}_{\mathrm{L}} \quad$ Uniformly distributed load on the shell body projection which represents the live load applied on the dome in the calculations.

$\Phi \quad$ Vertical angle with shell vertex.

\section{INTRODUCTION}

As a result of considerable technical development, shells have found nowadays a vast range of application in construction, aviation, machine building, naval construction, and in many other fields. Their spatial behavior, which is particularly beneficial, allows the shell thickness to be reduced to a minimum; i.e. according to M. Soare ${ }^{(6)}$ the ratio of normal radius of curvature to shell thickness about $1 / 20$ may be taken to be a limiting value for the applicability of the theory of these shells.

This research deals with the comparison between membrane theory and finite element analyses for domed shells with considering the support ring beam in calculations.

This research aims to suggest a way to use the solution of membrane theory formulas to get a quick and accurate analysis for spherical shells.

Tables and figures were prepared in order to make the results of the comparison obvious and effective.

\section{ANALYSIS OF SPHERICAL DOMED SHELLS}

Spherical domed shell according to membrane theory ${ }^{(1,2,3 \& 4)}$ can be analyzed as following, see figure (1):

1- Due to self-weight: 


$$
\begin{aligned}
& T=-W_{D} r \frac{1}{1+\cos \phi} \\
& H=W_{D} r\left(\frac{1}{1+\cos \phi}-\cos \phi\right)
\end{aligned}
$$

2- Due to crown concentrated force:

$$
\begin{gathered}
T=-C \frac{1}{2 \pi r \sin ^{2} \phi} \\
H=C \frac{1}{2 \pi r \sin ^{2} \phi}
\end{gathered}
$$

3- Due to live load:

$$
\begin{aligned}
& T=-W_{L} \frac{r}{2} \\
& H=-W_{L} \frac{r}{2} \cos 2 \phi
\end{aligned}
$$

For the finite element solution a 4-noded plate element is used to analyze the considered shell and a 2-noded beam element is used to simulate the support ring beam.

\section{NUMERICAL EXAMPLE}

Figure (2) shows an example of a concrete spherical domed shell with a uniform thickness of $0.2 \mathrm{~m}$ with a radius of $20 \mathrm{~m}$ carries an ornament of $3 \mathrm{kN}$ and distributed live load $\mathrm{W}_{\mathrm{L}}=4 \mathrm{kN} / \mathrm{m}^{2}$ will be used to illustrate the comparison between membrane theory and finite element solutions.

An imaginary load case is considered in table (1) which is analyzing the domed shell of the example above due to crown concentrated force only (ignoring self-weight) in order to see the effect of the crown concentrated load separately on the shell.

It is clear in table (1) in addition to Figures $(3 \& 4)$ that at the shell crown where $\varphi=0^{\circ}$ both $\mathrm{T}$ and $\mathrm{H}$ are infinity which is illogical; while finite element gives acceptable values for $\mathrm{T}_{\mathrm{FS}}$, $\mathrm{H}_{\mathrm{FS}}, \mathrm{T}_{\mathrm{SS}}$ and $\mathrm{H}_{\mathrm{SS}}$. But, the values $\mathrm{T}$ and $\mathrm{H}$ become compatible with $\mathrm{T}_{\mathrm{FS}}, \mathrm{H}_{\mathrm{FS}}, \mathrm{T}_{\mathrm{SS}}$ and $\mathrm{H}_{\mathrm{SS}}$ after approximately $\varphi=5^{\circ}$ and become logical too.

Also it is worth to notice in the figures $(5,6,7$ and 8) as well as table (1) that the analyzed forces due to crown concentrated load vanish and could be negligible after $\varphi=18^{\circ}$. We see that in the case of crown concentrated force only, the effect of the shell support type is approximately negligible in both membrane theory and finite element analyses for the same reason mentioned above because after $\varphi=18^{\circ} \mathrm{T}$ and $\mathrm{H}$ become approximately zero. 
The analysis results shown in table (2) in addition to Figures $(9,10,11,12,13,14)$ are for the case of live load only (ignoring self-weight) which present a very good convergence between the two methods of analysis except at the support narrow zone i.e. where $\varphi=24^{\circ}$ to $\varphi=30^{\circ}$.

Table (3) and figures (17, 18, 19 and 20) represent the analysis results for the case of self-weight only which shows a very good convergence between the two methods of analysis except at the support narrow zone i.e. where $\varphi=24^{\circ}$ to $\varphi=30^{\circ}$.

The justification of these differences could be explained by the incompatibility happened in the support zone between contrastive forces near the support. In the support narrow strip there is compression hoop forces $\mathrm{H}$, because of compression, the shell tends to reduce the diameter of its edge by contraction; on the other hand, the tension ring beam tends to enlarge its diameter because of the horizontal component $\mathrm{F}$ of the thrust force $\mathrm{T}$, see figure (1). Obviously, both deformations cannot take place at the same time. The conditions of deformation are incompatible with the membrane theory.

Finally, it is worth to mention here that due to crown concentrated force only (ignoring self-weight), the crown narrow zone could be effected by this load and the effect vanishes after $\varphi=15^{\circ}$ to the degree that it could be said that it could be ignored, see table (4).

\section{TENSION HOOP FORCES INVESTIGATIONS}

Table (4) shows the analysis results given by membrane theory formulas (from 1 to 6 ) for various values of vertical angle $\varphi$. The self-weight is represented in terms of $W_{D} . r$, live load represented in terms of $\mathrm{W}_{\mathrm{L}} \cdot \mathrm{r}$ while crown concentrated load represented in terms of $\frac{C}{r}$.

It is noted that due to self-weight only, the hoop forces $\mathrm{H}$ from $\varphi=0^{\circ}$ are compression till $\varphi=51^{\circ} 48^{\prime}$. At $\varphi=51^{\circ} 48^{\prime} \mathrm{H}$ become zero, then $\mathrm{H}$ become tension after $\varphi=51^{\circ} 48^{\prime}$ till $\varphi=90^{\circ}$.

It is also noted that the hoop forces $\mathrm{H}$ due to live load only (ignoring self-weight) starts at $\varphi=0^{\circ}$ with compression forces till $\varphi=45^{\circ}$ where the hoop forces $\mathrm{H}$ equal zero, then hoop forces $\mathrm{H}$ become tension from $\varphi=45^{\circ}$ till $\varphi=90^{\circ}$.

\section{CONCLUSION}

1- In the load case of crown concentrated force only applied on the crown of the shell like crown lantern or ornament (ignoring self-weight); it is clear that the effect of that 
force takes place only in the crown zone and in both fixed or simply supported boundary conditions.

2- It is seen that the results given by formulas $(3 \& 4)$ are so compatible with the finite element solution except for the crown zone. So, it is recommended here to use these formulas but with avoiding the results given for $\varphi=0^{\circ}$ to $5^{\circ}$, i.e. use $\varphi=5^{\circ}$ instead of $\varphi=0^{\circ}$.

3- In the load cases of self-weight or live load and for both fixed or simply supported boundary conditions, it is obvious that the results given by formulas $(1,2,5 \& 6)$ are so compatible with the finite element solution except for the narrow boundary strip. So, it is recommended here to use these formulas but with avoiding the results given for the boundary narrow strip.

4- Membrane theory analysis does not take into consideration the type of shell support while finite element solution gives the real behavior of the shell within support type change.

\section{REFERENCES}

1. Baker, E. H., "Structural Analysis of Shells", McGraw-Hill Book Kovalesky, L. and Company, Inc., United States of America, 1972.

Rish, F.L.

2. Gibson, J. E.

"Thin Shells, Computing and Theory", The City University, London 1980.

3. Gioncu, V.

"Thin Reinforced Concrete Shells", John Wiley and

4. Heyman, J. Sons, ltd., Printed in Romania, 1979.

4.

"Equilibrium of Shell Structures", Oxford University Press., Great Britain, 1977.

5. Smith E. B. “The Dome”, Princeton University Press, 1978.

6. Soare, Mircea

"Application of F.D. Equations to shell analysis" Program Press, Bucharest. 
Table (1):Comparison between Membrane Theory and Finite Element analyses in the case of crown concentrated force only (ignoring self-weight).

\begin{tabular}{|c|c|c|c|c|c|c|}
\hline \multirow{2}{*}{$\begin{array}{c}\varphi \\
\text { (degrees) }\end{array}$} & \multicolumn{2}{|c|}{$\begin{array}{c}\text { Membrane Theory } \\
(\mathrm{kN} / \mathrm{m})\end{array}$} & \multicolumn{2}{c|}{$\begin{array}{c}\text { Finite Element (kN/m) } \\
\text { (Fixed Support) }\end{array}$} & \multicolumn{2}{|c|}{$\begin{array}{c}\text { Finite Element (kN/m), } \\
\text { (Pinned Support) }\end{array}$} \\
\cline { 2 - 7 } & $\mathrm{T}$ & $\mathrm{H}$ & $\mathrm{T}_{\mathrm{FS}}$ & $\mathrm{H}_{\mathrm{FS}}$ & $\mathrm{T}_{\mathrm{SS}}$ & $\mathrm{H}_{\mathrm{SS}}$ \\
\hline 0 & $\infty$ & $\infty$ & -3.24 & 2.26 & -3.24 & 2.26 \\
\hline 1 & -78.37 & 78.37 & -2.94 & 2.0 & -3.02 & 2.01 \\
\hline 2 & -19.6 & 19.6 & -2.64 & 1.74 & -2.8 & 1.76 \\
\hline 3 & -8.715 & 8.715 & -2.34 & 1.48 & -2.58 & 1.54 \\
\hline 4 & -4.9 & 4.9 & -2.04 & 1.22 & -2.36 & 1.29 \\
\hline 5 & -3.15 & 3.15 & -1.74 & 0.96 & -2.14 & 1.04 \\
\hline 6 & -2.18 & 2.18 & -1.42 & 0.02 & -1.92 & 0.06 \\
\hline 12 & -0.55 & 0.55 & -0.54 & 0.62 & -0.72 & 0.62 \\
\hline 18 & -0.25 & 0.25 & -0.22 & 0.32 & -0.3 & 0.32 \\
\hline 24 & -0.144 & 0.144 & -0.12 & 0.2 & -0.16 & 0.2 \\
\hline 30 & -0.095 & 0.095 & -0.08 & 0.26 & -0.08 & 0.26 \\
\hline
\end{tabular}

Table (2): Comparison between Membrane Theory and Finite Element analyses in the case of live load only (ignoring self-weight).

\begin{tabular}{|c|c|c|c|c|c|c|}
\hline \multirow{2}{*}{$\begin{array}{c}\varphi \\
(\text { degrees })\end{array}$} & \multicolumn{2}{|c|}{$\begin{array}{c}\text { Membrane Theory } \\
(\mathrm{kN} / \mathrm{m})\end{array}$} & \multicolumn{2}{c|}{\begin{tabular}{c}
\multicolumn{2}{c|}{ Finite Element (kN/m) } \\
(Fixed Support)
\end{tabular}} & \multicolumn{2}{|c|}{$\begin{array}{c}\text { Finite Element (kN/m), } \\
\text { (Pinned Support) }\end{array}$} \\
\cline { 2 - 7 } & $\mathrm{T}$ & $\mathrm{H}$ & $\mathrm{T}_{\mathrm{FS}}$ & $\mathrm{H}_{\mathrm{FS}}$ & $\mathrm{T}_{\mathrm{SS}}$ & $\mathrm{H}_{\mathrm{SS}}$ \\
\hline 0 & -40 & -40 & -40.4 & -39.9 & -46.6 & -46.2 \\
\hline 6 & -40 & -39.2 & -39.7 & -38.3 & -46.02 & -44.86 \\
\hline 12 & -40 & -36.5 & -39.84 & -39.4 & -46.64 & -46.74 \\
\hline 18 & -40 & -32.4 & -41.24 & -38.2 & -48.48 & -45 \\
\hline 24 & -40 & -26.76 & -39.8 & 3.6 & -46.74 & 5.1 \\
\hline 30 & -40 & -20 & -30 & 85.3 & -35.1 & 101.4 \\
\hline
\end{tabular}

Table (3): Comparison between Membrane Theory and Finite Element analyses in the case of self-weight only.

\begin{tabular}{|c|c|c|c|c|c|c|}
\hline \multirow{2}{*}{$\begin{array}{c}\varphi \\
\text { (degrees) }\end{array}$} & \multicolumn{2}{|c|}{$\begin{array}{c}\text { Membrane Theory } \\
(\mathrm{kN} / \mathrm{m})\end{array}$} & \multicolumn{2}{|c|}{$\begin{array}{c}\text { Finite Element (kN/m) } \\
\text { (Fixed Support) }\end{array}$} & \multicolumn{2}{|c|}{$\begin{array}{c}\text { Finite Element (kN/m), } \\
\text { (Pinned Support) }\end{array}$} \\
\cline { 2 - 7 } & $\mathrm{T}$ & $\mathrm{H}$ & $\mathrm{T}_{\mathrm{FS}}$ & $\mathrm{H}_{\mathrm{FS}}$ & $\mathrm{T}_{\mathrm{SS}}$ & $\mathrm{H}_{\mathrm{SS}}$ \\
\hline 0 & -49 & -49 & -46.7 & -46.1 & -46.7 & -46.14 \\
\hline
\end{tabular}


COMPARISON BETWEEN MEMBRANE THEORY AND FINITE ELEMENTS ANALYSES FOR DOMED SHELLS EDGED BY SUPPORT RING BEAM

\begin{tabular}{|c|c|c|c|c|c|c|}
\hline 6 & -49.13 & -48.33 & -46 & -44.86 & -46.1 & -44.9 \\
\hline 12 & -49.54 & -46.32 & -46.6 & -46.7 & -46.6 & -46.74 \\
\hline 18 & -51.23 & -42.97 & -48.48 & -45.2 & -48.5 & -45 \\
\hline 24 & -51.21 & -38.3 & -46.8 & 4.6 & -46.8 & 5.1 \\
\hline 30 & -52.52 & -32.35 & -35.2 & 101.8 & -35.2 & 101.4 \\
\hline
\end{tabular}

Table (4): Analysis of membrane theory for a self-weight, live load and a lantern load cases separately.

\begin{tabular}{|c|c|c|c|c|c|c|}
\hline \multirow[b]{2}{*}{$\begin{array}{c}\Phi \\
\text { (deg.) }\end{array}$} & \multicolumn{2}{|c|}{ Load of self-weight } & \multicolumn{2}{|c|}{$\begin{array}{l}\text { Load C at crown (lantern } \\
\text { or ornament) }\end{array}$} & \multicolumn{2}{|c|}{ Live load } \\
\hline & $\begin{array}{c}\text { Meridional } \\
\text { thrusts (T) } \\
\text { Coefficient } \\
\text { of } \mathrm{W}_{\mathrm{D}} \cdot \mathrm{r}\end{array}$ & $\begin{array}{c}\text { Hoop } \\
\text { forces } \\
(\mathrm{H}) \\
\text { Coefficient } \\
\text { of } \\
\mathrm{W}_{\mathrm{D} . \mathrm{r}}\end{array}$ & $\begin{array}{l}\text { Meridional } \\
\text { thrusts (T) } \\
\text { Coefficient } \\
\quad \text { of } \frac{C}{r}\end{array}$ & $\begin{array}{c}\text { Hoop } \\
\text { forces }(\mathrm{H}) \\
\text { Coefficient } \\
\text { of } \frac{C}{r}\end{array}$ & $\begin{array}{c}\text { Meridional } \\
\text { thrusts (T) } \\
\text { Coefficient } \\
\text { of } W_{L} \cdot r\end{array}$ & $\begin{array}{c}\text { Hoop } \\
\text { forces } \\
(\mathrm{H}) \\
\text { Coefficient } \\
\text { of } \mathrm{W}_{\mathrm{L} .} \mathrm{r}\end{array}$ \\
\hline 0 & -0.5 & -0.5 & $\infty$ & $\infty$ & -0.5 & -0.5 \\
\hline 1 & -0.5 & -0.499 & -522.5 & 522.5 & -0.5 & -0.499 \\
\hline 2 & -0.5 & -0.499 & -130.67 & 130.67 & -0.5 & -0.498 \\
\hline 3 & -0.5 & -0.498 & -58.1 & 58.1 & -0.5 & -0.497 \\
\hline 4 & -0.5 & -0.497 & -32.7 & 32.7 & -0.5 & -0.495 \\
\hline 5 & -0.5 & -0.496 & -21.0 & 21.0 & -0.5 & -0.492 \\
\hline 6 & -0.501 & -0.493 & -14.56 & 14.56 & -0.5 & -0.489 \\
\hline 7 & -0.501 & -0.49 & -10.71 & 10.71 & -0.5 & -0.485 \\
\hline 8 & -0.502 & -0.487 & -8.21 & 8.21 & -0.5 & -0.48 \\
\hline 9 & -0.503 & -0.484 & -6.5 & 6.5 & -0.5 & -0.475 \\
\hline 10 & -0.505 & -0.48 & -5.3 & 5.3 & -0.5 & -0.469 \\
\hline 20 & -0.516 & -0.425 & -1.37 & 1.37 & -0.5 & -0.383 \\
\hline 30 & -0.537 & -0.33 & -0.64 & 0.64 & -0.5 & -0.25 \\
\hline 40 & -0.566 & -0.2 & -0.38 & 0.38 & -0.5 & -0.173 \\
\hline 45 & -0.585 & -0.122 & -0.318 & 0.318 & -0.5 & 0.00 \\
\hline 50 & -0.608 & -0.034 & -0.27 & 0.27 & -0.5 & -0.086 \\
\hline $51^{\circ} 48^{\prime}$ & -0.618 & 0.00 & -0.26 & 0.26 & -0.5 & -0.117 \\
\hline 60 & -0.667 & +0.167 & -0.21 & 0.21 & -0.5 & -0.25 \\
\hline 70 & -0.747 & +0.402 & -0.18 & 0.18 & -0.5 & -0.766 \\
\hline 80 & -0.838 & +0.68 & -0.16 & 0.16 & -0.5 & -0.469 \\
\hline 90 & -1.00 & +1.00 & -0.16 & 0.16 & -0.5 & -0.5 \\
\hline
\end{tabular}




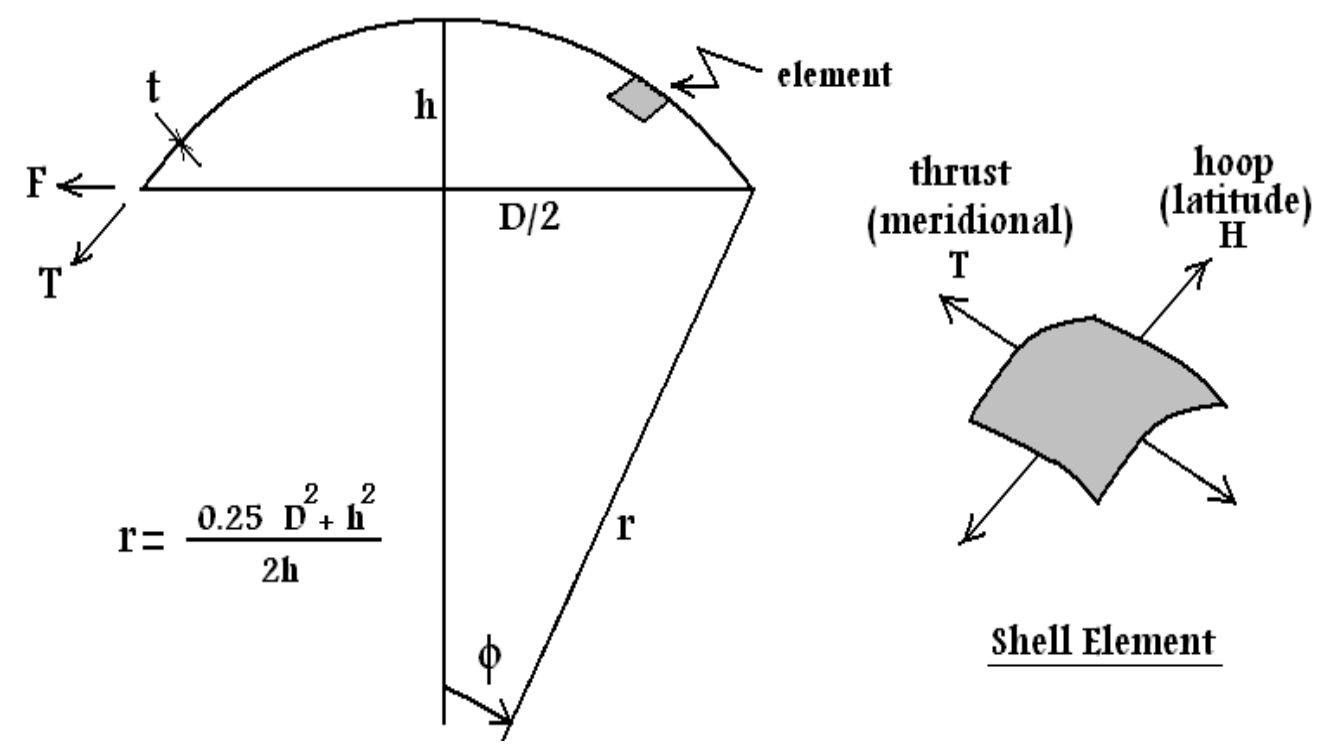

Figure (1): The used notations and forces positive directions.

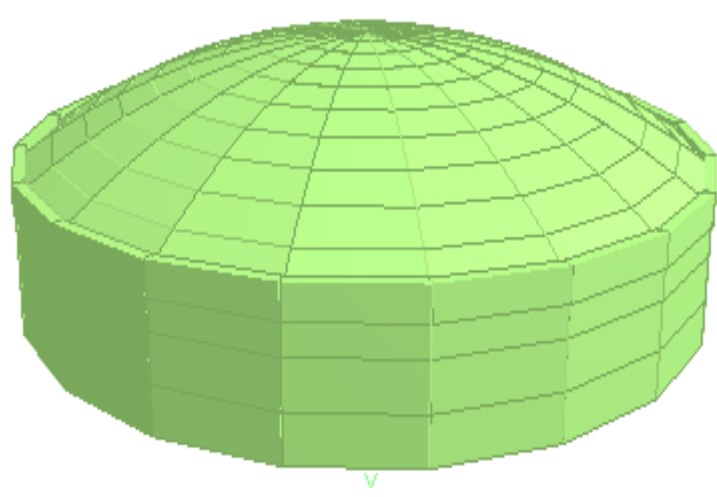

$\underline{\text { Dome }}$

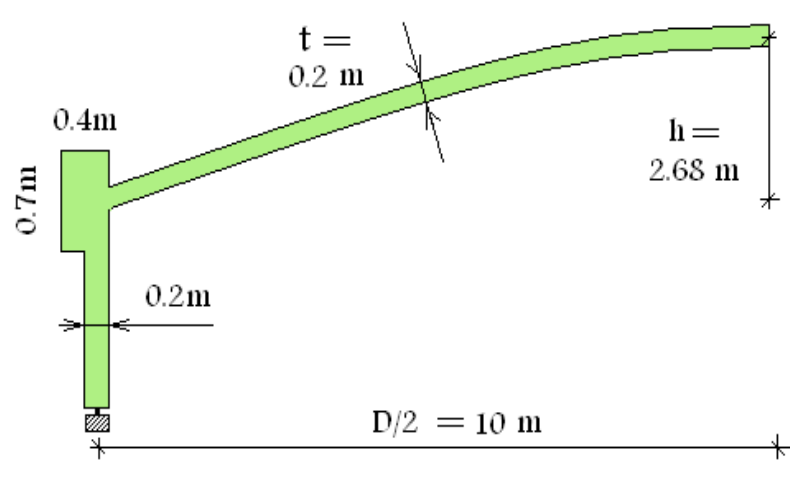

$\underline{\text { Cross section }}$

Figure (2): The dome of the study case and the dimensions in details 

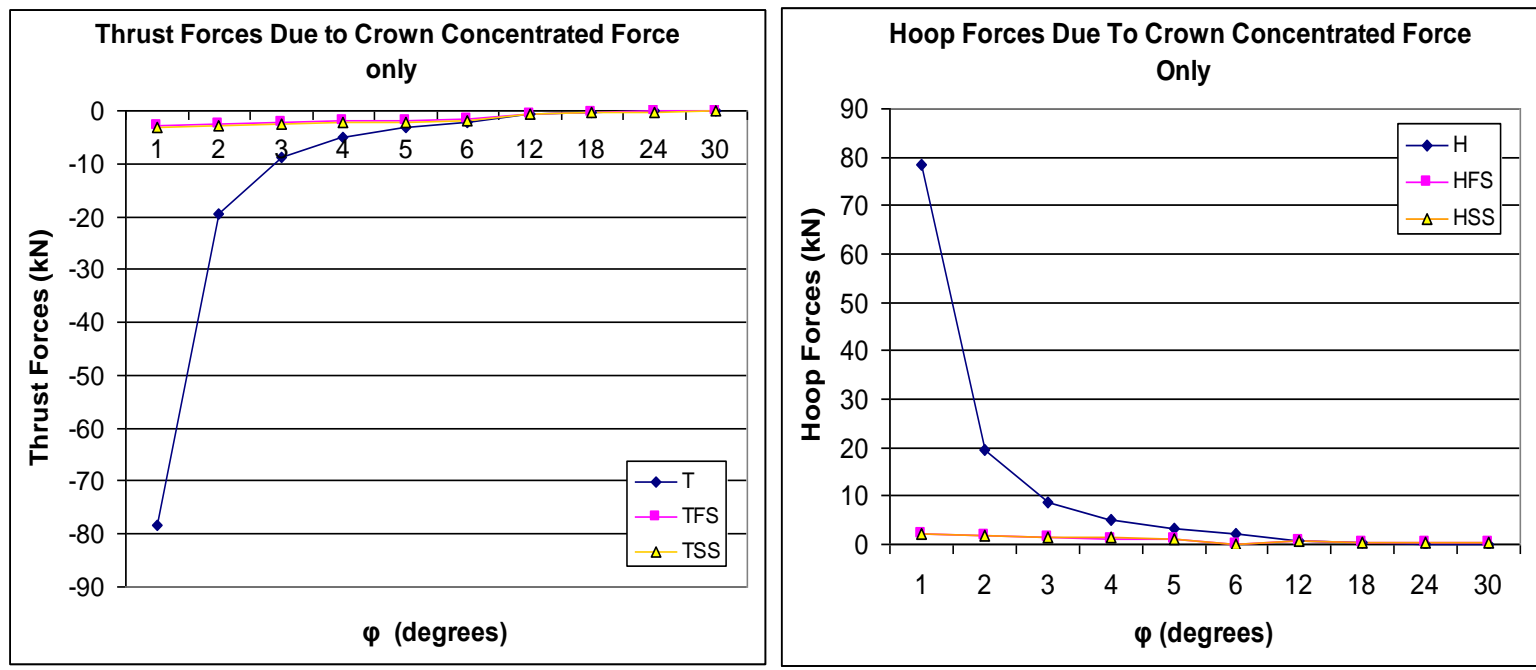

Figure (3) \& Figure (4): Thrust and Hoop stresses due to crown concentrated load only (ignoring self-weight) with both fixed and pinned supports

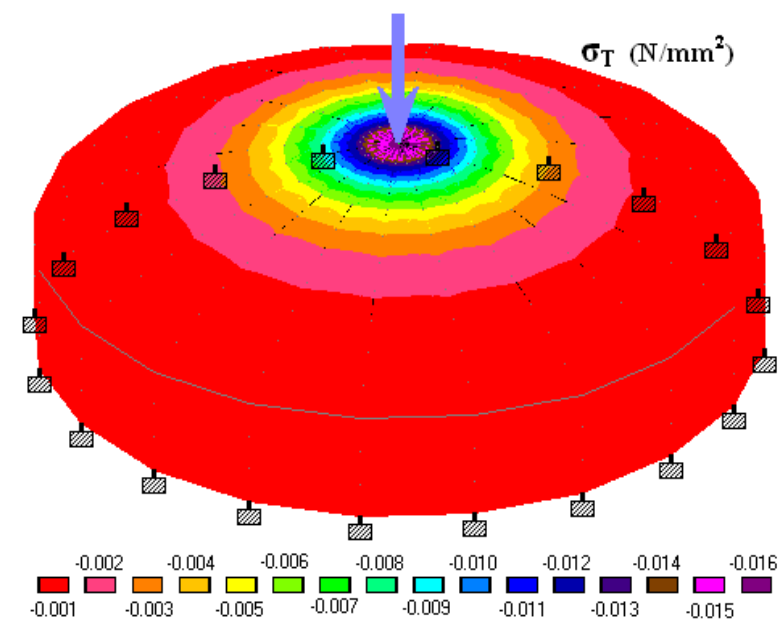

Figure (5): Thrust stresses due to crown concentrated load only (ignoring self-weight) with fixed support.

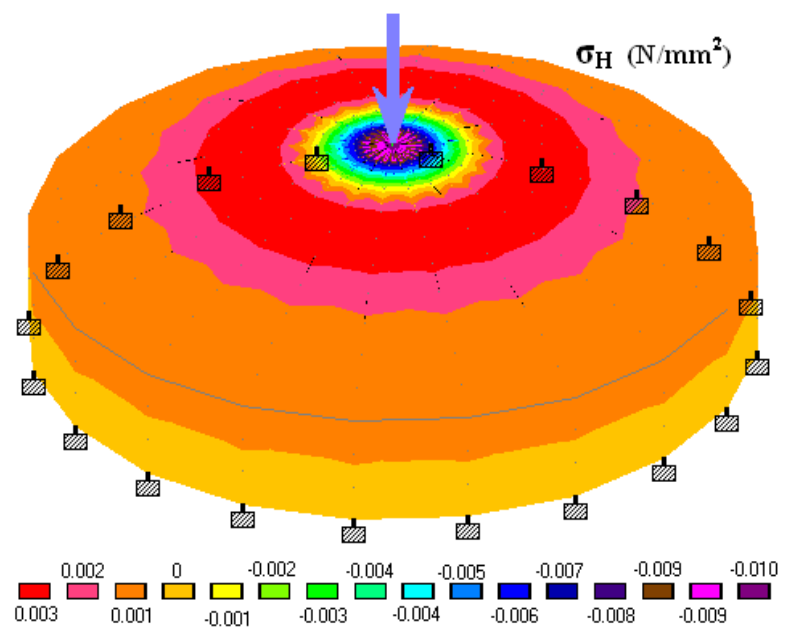

Figure (6): Hoop stresses due to crown concentrated load only (ignoring self-weight) with fixed support. 


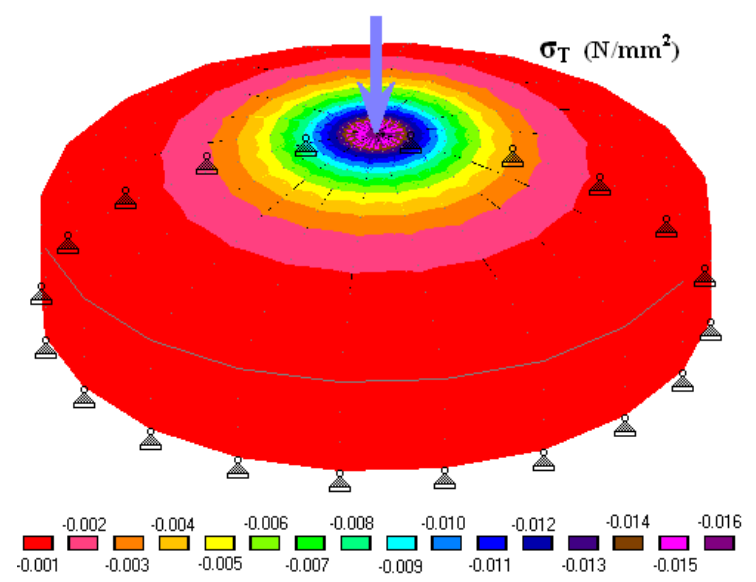

Figure (7): Thrust stresses due to crown concentrated load only (ignoring selfweight) with pinned support.

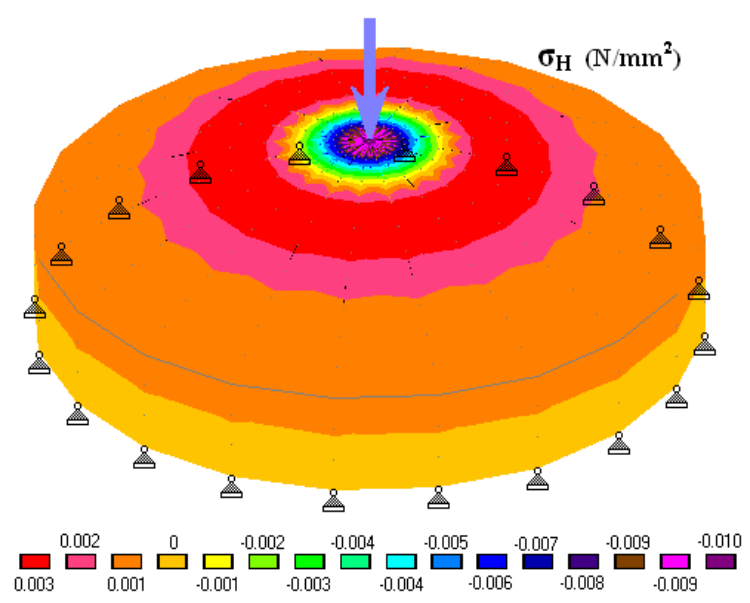

Figure (8): Hoop stresses due to crown concentrated load only (ignoring selfweight) with pinned support.
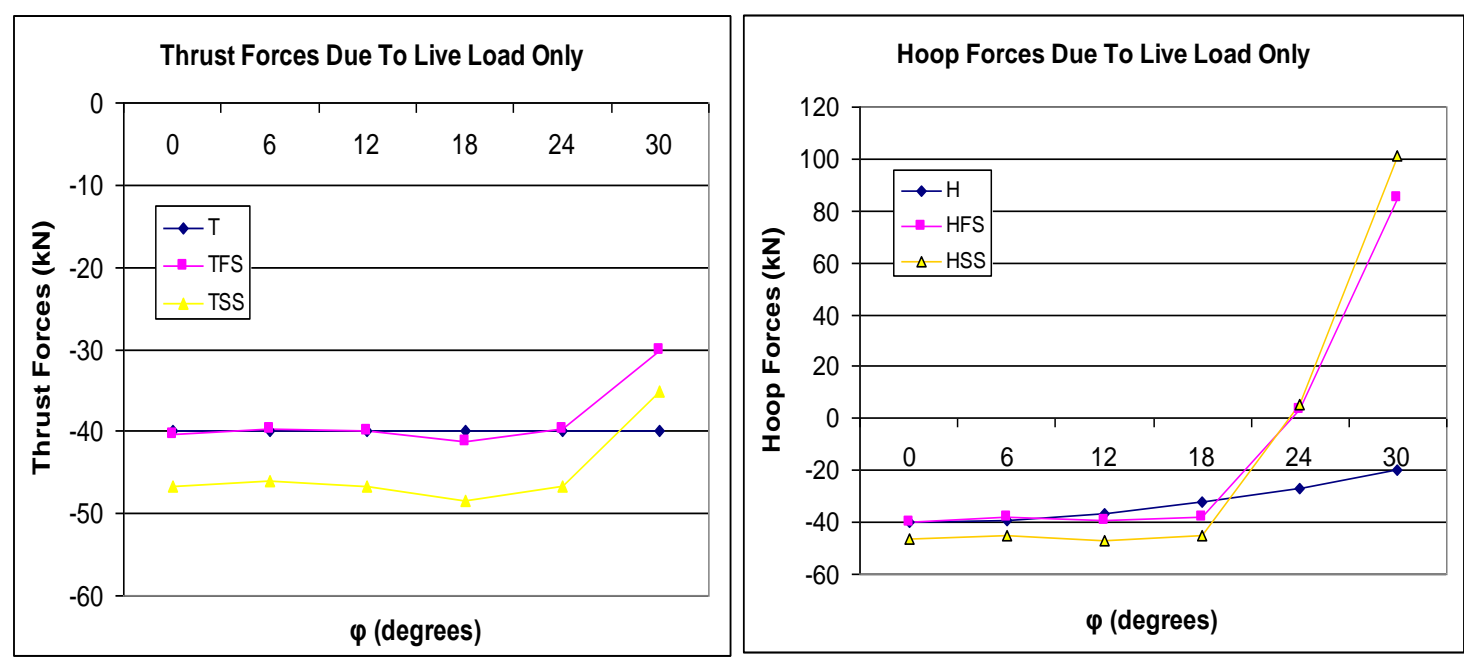

Figures (9) and Figure (10): Thrust and Hoop stresses due to live load only (ignoring self-weight) with both fixed and pinned supports. 


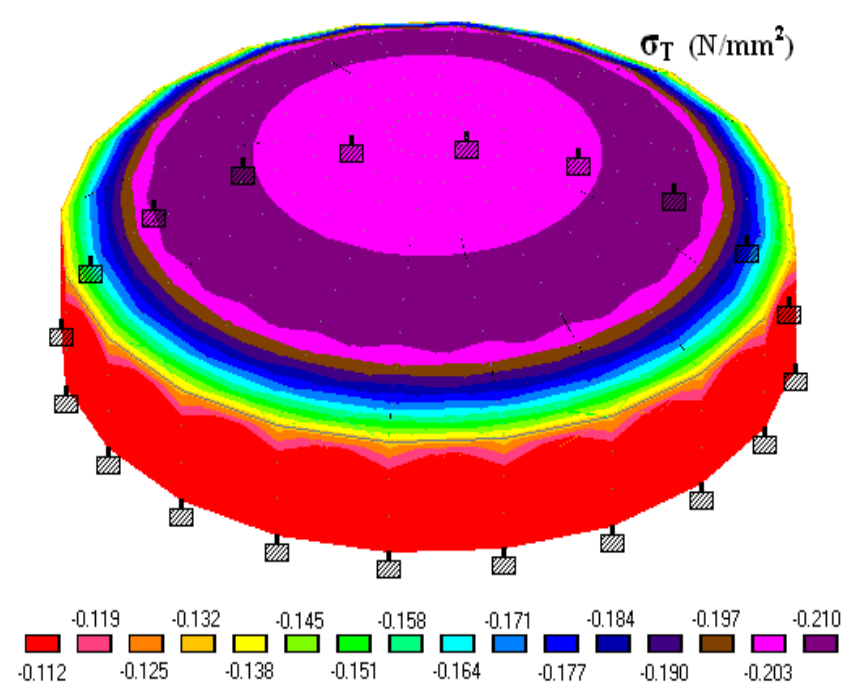

Figure (11): Thrust stresses due to live load only (ignoring self-weight) with fixed support.

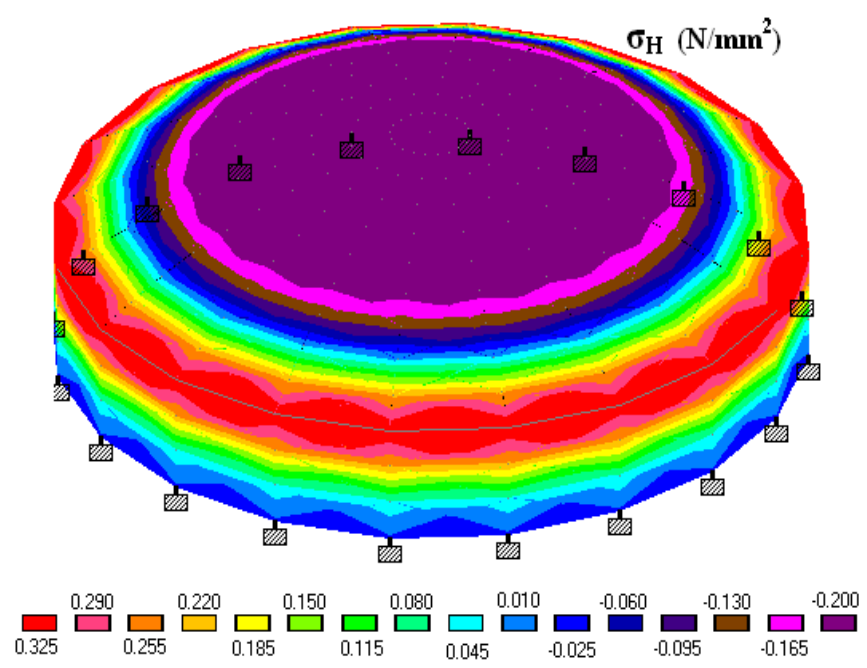

Figure (12): Hoop stresses due to live load only (ignoring self-weight) with fixed support.

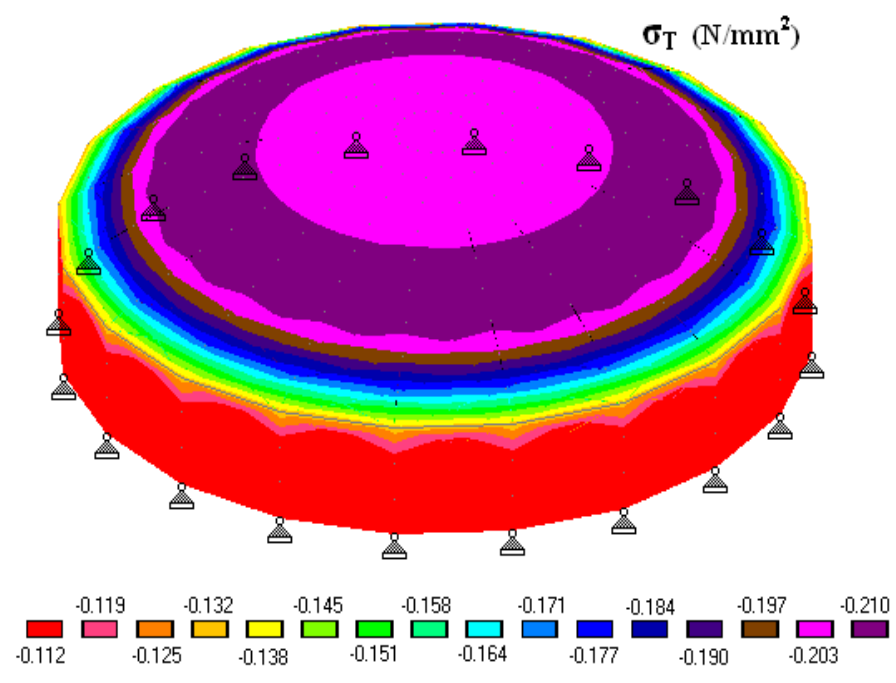

Figure (13): Thrust stresses due to live load only (ignoring self-weight) with pinned support. 


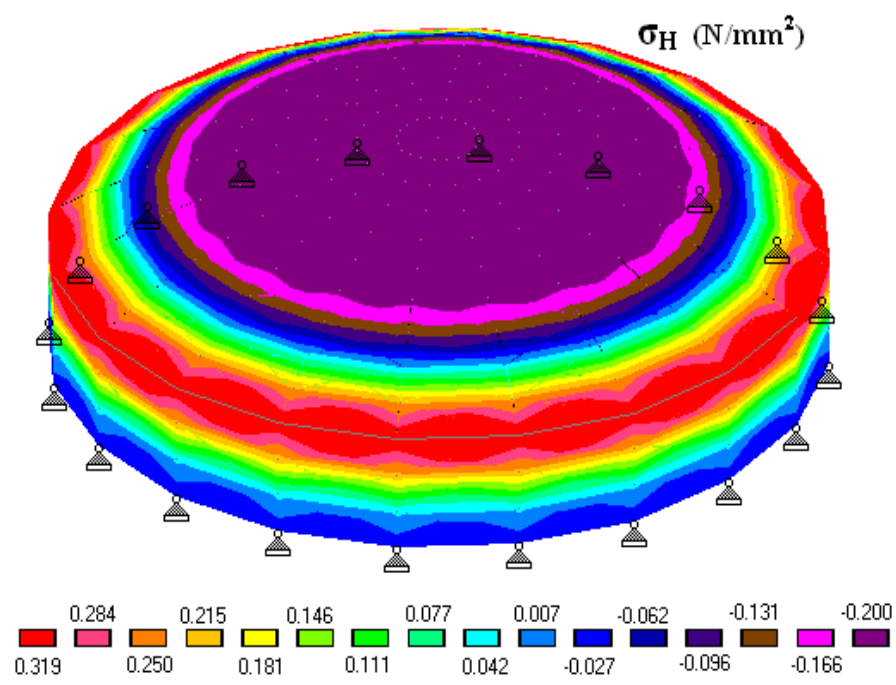

Figure (14): Hoop stresses due to live load only (ignoring self-weight) with pinned support.
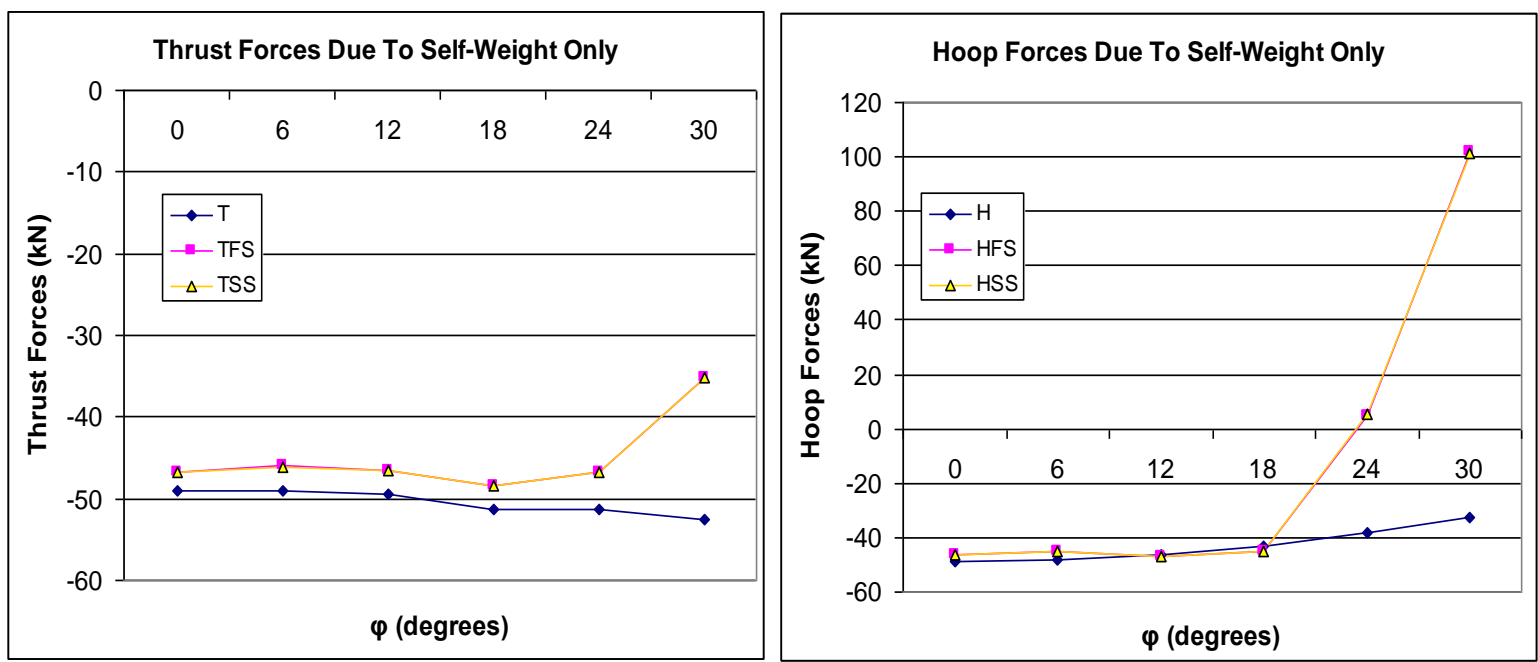

Figure (15) and Figure (16): Thrust and Hoop stresses due to self-weight only (ignoring selfweight) with both fixed and pinned supports.

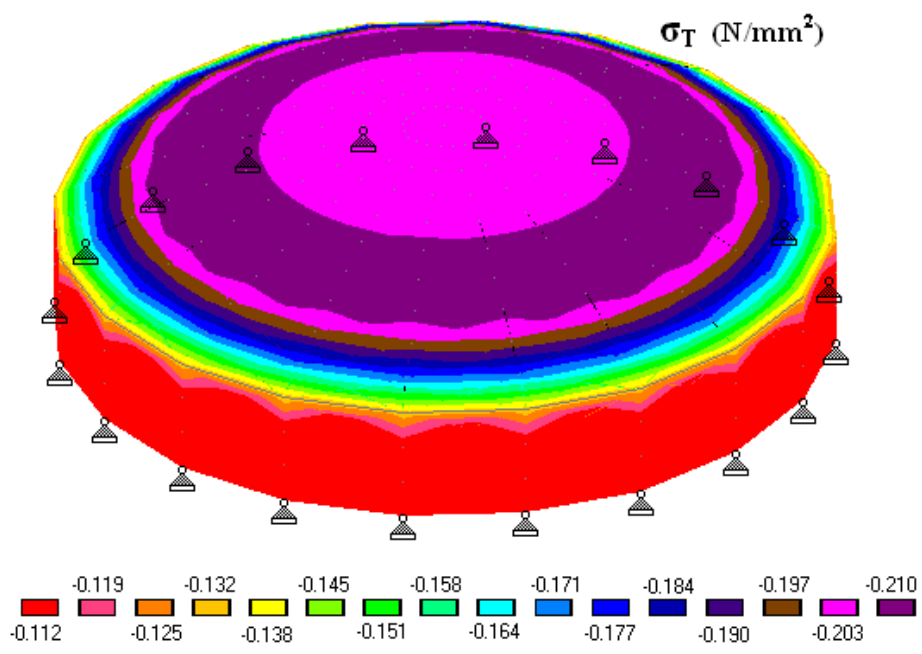

Figure (17): Thrust stresses due to self-weight with pinned support. 


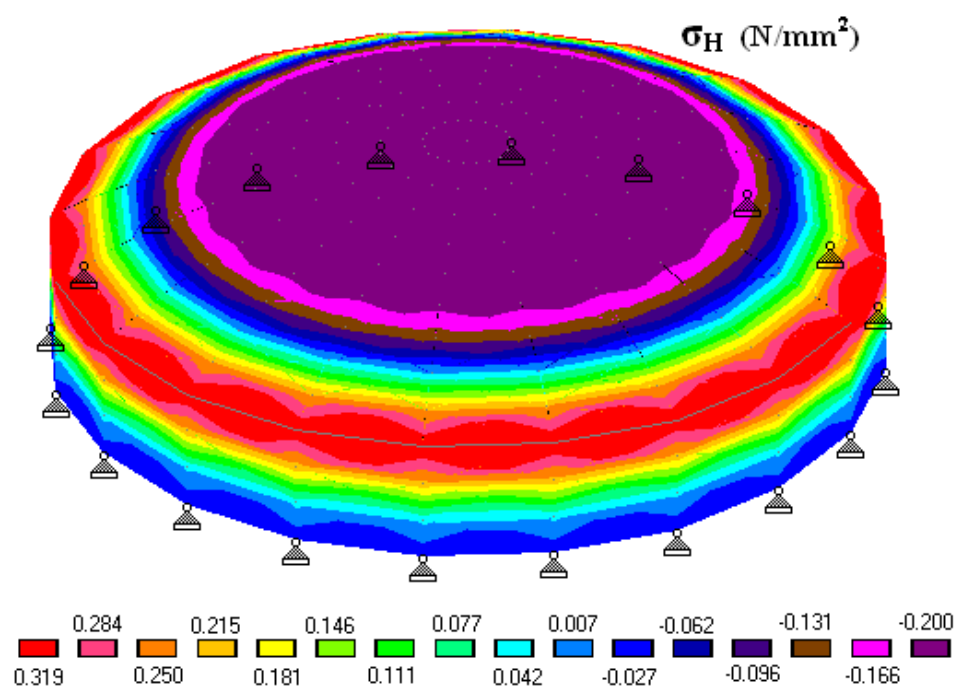

Figure (18): Hoop stresses due to self-weight with pinned support.

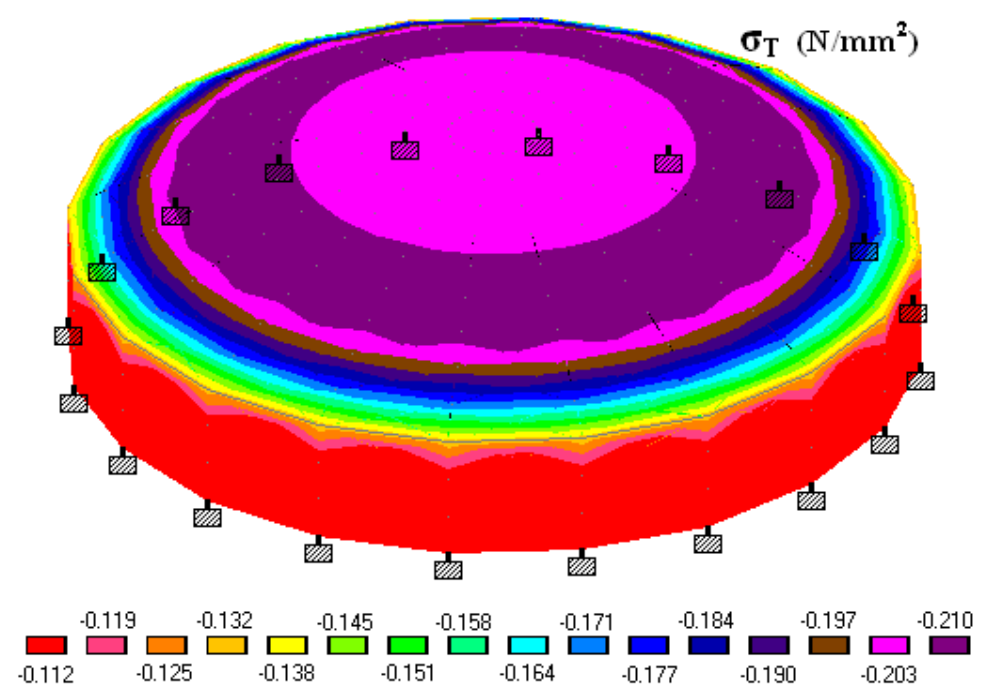

Figure (19): Thrust stresses due to self-weight with fixed support.

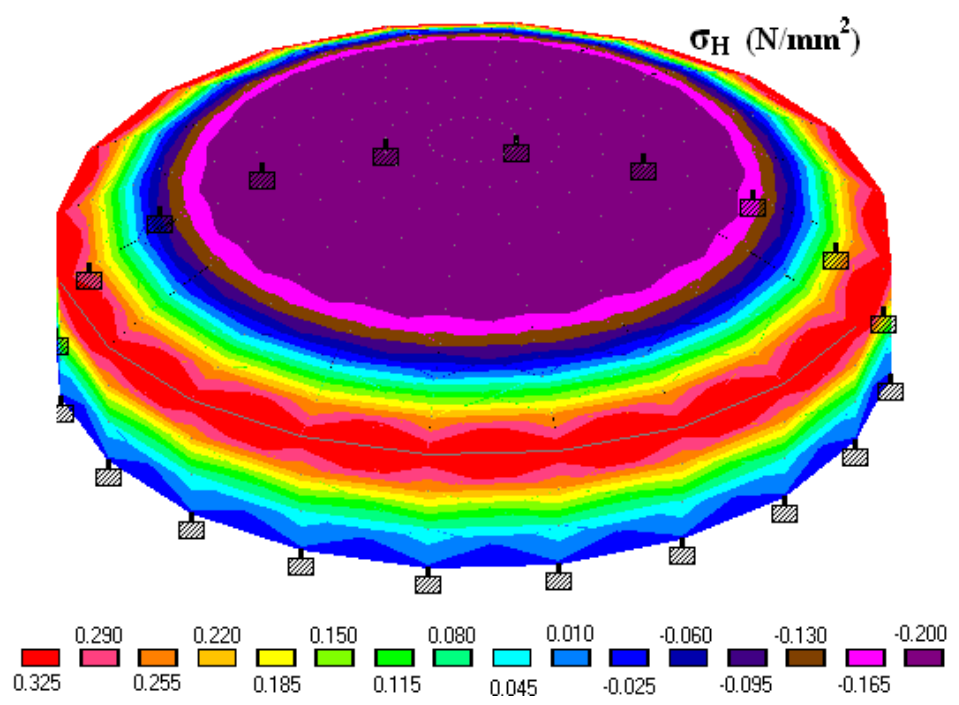

Figure (20): Hoop stresses due to self-weight with fixed support. 


\section{المقارنة ما بين نظرية الغشاء و طريقة العناصر المحدة في تحليل القباب القشرية المرتبطة بجسر المسند المحيطي}

$$
\text { علي حسين حميد }
$$

$$
\text { وعد عبد الستار حسين }
$$

كلية الهندسة/ جامعة ديالى/ قسم الهندسة المدنية
خطاب سليم عبد الرزاق

الخلاصة

تعود القباب للظهور مرة اخرى في العراق لتلخل هذه المرة تصاميم البيوت للمواطنين الذي برون بها هوية المعمار العراقي و رمز من رموز الاصالة والجمال و الابهة في نفس الوقت. فنلاحظها تتفذ الان بكثرة سواء كانت مبنية من الطابوق او الخرسانة المسلحة او حتى من الهياكل الحديدية. بل جمعت بعض البيوت عدة قباب منها المنقرقة و منها المتداخلة. و بذللك اصبح من الضروري ان نكون ملمين بمعرفة تصرف القبة و كيفية توزيع الاجهادات التي فيها كي تُّلل و تُّمدم بطريقة سريعة و دقيقة. و هنا يأتي هذا الجها المتواضع ليسلط الضوء على النتائج المستحصلة من دراسةالمقارنة بين نتائج طريقة

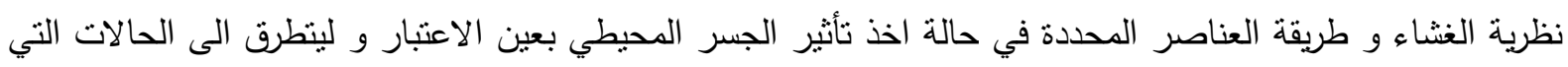
لا يمكن اعتماد نتائج طريقة نظرية الغشاء السهلة و السريعة بشكل مباشر و التوصية بنصائح كي يكون استخدام طريقة

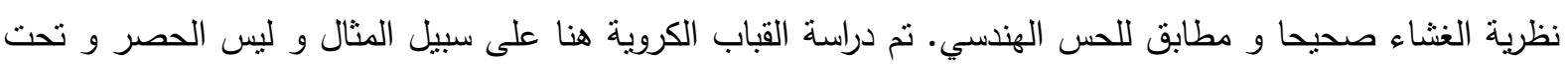
تأثثر عدة انواع من التحميل للحصول على النتائج التي نم مناقشتها و التوصل الى بعض التوصيات المثنتة بهذا البحث. 